\title{
Empowering a Family Welfare Movement Group through Lady Kaka
}

\section{Hamia $^{1 *}$, Irnawati ${ }^{2}$, Muhammad Wahyu ${ }^{3}$,Sakina Amaliah Pratiwi ${ }^{4}$, Wahyudin ${ }^{5}$}

1,4Department of Biology, Faculty of Mathematics and Science, Universitas Negeri Makassar, Makassar, Indonesia

${ }^{2}$ Department of Sociology, Faculty of Social Studies, Universitas Negeri Makassar, Makassar, Indonesia

${ }^{3}$ Department of Geography, Faculty of Mathematics and Science, Universitas Negeri Makassar, Makassar, Indonesia

${ }^{5}$ Department of Chemistry, Faculty of Mathematics and Science, Universitas Negeri Makassar, Makassar, Indonesia

Submitted: June 24 ${ }^{\text {th }}$ 2019; Revised: November 30 th November 2020; Accepted: March $12^{\text {th }} 2021$

Keywords:
Training
Black soldier fly
Cultivation
Organic waste
Family welfare
Empowerment

Abstract The program aims to improve the knowledge and welfare of the Family Welfare Empowerment or abbreviated as PKK group through cultivation of Black Soldier Fly (BSF) and reduce organic waste by utilizing it as BSF growing media. Reusing organic waste is an effective way to reduce waste such as vegetables and fruits. Increasing organic waste in Sungguminasa Central Market causes the society needs in knowledge and information on managing the organic waste to become economically valuable products. Based on the observations, the black soldier fly program as fish feed in term (Lady Kaka) was used as main solution because BSF in maggot phase consumes the organic waste. The program involves seven people from PKK group with majority of housewives who do not have fixed income. The implementation of this program consists of 3 phases, namely initial preparation phase which includes observation, administration, and provision of tools and materials, implementation phase which includes training and activation of PKK group, and the last is monitoring and evaluation phase. The results achieved were the transfer of knowledge through training activities to PKK group about BSF cultivation and its management to become fish feed and product marketing to increase the productivity and prosperity of PKK group as well as reducing the trash in Sungguminasa Central Market due to being utilized as growing media of BSF.

\section{INTRODUCTION}

With the increase of population, waste production in Indonesia is also increasing. Data from the Ministry of Environment and Forestry shows that the total waste produced by Indonesian reached 187.2 million tons per year (Pikiran Rakyat, 2017). Based on the latest research conducted by Sustainable Waste Indonesia (SWI) as quoted in CNN Indonesia website (2018), the type of waste produced the most was organic waste
(60\%), followed by inorganic wastes consisting of plastic waste $(14 \%)$, paper waste $(9 \%)$, metal $(4.3 \%)$, and glass, wood, and other materials (12.7\%). The waste originated from household consumption, agriculture, trade, offices, and industry. One of the highest contributors of trade waste in South Sulawesi is Sungguminasa Central Market located in Somba Opu District, Gowa Regency.

Sungguminasa Central Market is the largest market in Gowa; it is the shopping center for people

ISSN 2460-9447 (print), ISSN 2541-5883 (online)

${ }^{*}$ Corresponding author: Hamia

Department of Biology, Faculty of Mathematics and Science, Universitas Negeri Makassar, JI. A. P. Pettarani, Makassar 90222, Indonesia Email: Arifuddinmia14@gmail.com 
who live in Gowa and its surroundings. This market provides a wide range of necessities, for example: vegetables, home furniture, new or preloved clothing, fruits, and spices. The most common items sold in this market are vegetables and fruits; therefore, the type of waste produced the most is organic waste, the left over from the sellers. The large number of sellers adds to the waste production in Sugguminasa Central Market. In addition, the arrangement of goods and the lack of garbage bins have resulted in an unfavorable market arrangement. This is consistent with the news published by Korantempo.com (2016) stating that the Government of Gowa would reduce the number of registered sellers by 823 people, who had a total area of 9 hectares only. The number of sellers affects the amount of waste generated in the market.

The waste generated by the vegetable and fruit sellers are simply discarded near their stalls. The waste is transported using a garbage truck or Tangkasaki "Truk Angkutan Sampah Kita" (Our Garbage Transport Truck) to be taken to the landfill (TPA) located in Antang. Despite this effort, organic waste around the market is still piling up. Information obtained from TribunGowa.com (2018) mentioned that the government was targeting a free waste environment through household and household-like waste management program in 2018-2025. An effort to process the organic waste into products of economic value was made in order to support this government program. One of the animals utilized to break down the organic waste is the Black Soldier Fly (Hermetia illucens L.) abbreviated as BSF (Muhayyat et al., 2016).

The environmental conditions of the target community had exceeded the environment supporting capacity. This was due to the condition of the market, which was close to the settlements; therefore, there was a lot of vegetable and fruit waste that came from the market. The lack of knowledge and skills among the surrounding communities had made this waste become unutilized, and it piled up every day and was only transported to the landfill without any processing. Therefore, the people there need knowledge and information about the management of organic waste, turning it into products with economic value. The communities around the market who are the members of a Family Welfare Empowerment Group or Pemberdayaan Kesehjateraan Keluarga that abbreviated as PKK groups were the targets for this community service program.

The PKK group members of Batangkaluku generally worked as housewives and did not have regular income. The economic condition of this group could be classified as middle to lower class. They need skills to increase their income and welfare. Therefore, the right solution to capitalize the potential that existed in this village was through the community service program "Lady Kaka" (Black Soldier Fly as fish feed).

BSF is an insect that is able to break down organic waste, including vegetables, fruits, meat, and other organic wastes. BSF is also known as a high protein source, which is around $44 \%$, and fat source, around 29\% (Wardhana, 2016). BSF can be kept and mass bred. These animals can live in warm temperatures, but in extreme environmental conditions such as cold temperatures, BSF will become dormant. BSF can also live in media that contain lots of salt, alcohol, acid, and ammonia such as waste (Suciati \& Hilman, 2017). The existence of BSF inhibits the emergence of other organisms such as house flies which have many negative impacts on humans (Wisnawa \& Nyoman, 2017). In addition, BSF can live in the media such as vegetables or fruit that started to rot as the leftover of sales in the market is increasing in number.

The leftovers of sales in the market can be used as the growth medium for BSF because it contains nutrients that are good for its growth. In accordance with the findings of the study conducted by Fauzi \& Eka (2018), female BSF will lay their eggs in a growth medium with abundant food source in the form of organic waste. The use of organic leftovers from the sales would increase the awareness of the surrounding community of waste utilization, which was increasing along with the provision of degradable organic materials in the market. The skin of BSF larvae could then be used as fish feed; therefore, this required the community participation in terms of processing.

Community participation is one of the factors supporting the success of a program. According to Sandiasa and Ida (2017), community involvement can increase their ability to develop through experiences, training, and desires. This empowerment activity was expected with the result that the community could be actively involved in carrying out the planned program. This activity was a form of a concern in increasing public awareness of organic waste processing. A group that often exists in local communities is the PKK group that consists of women, the majority of whom are housewives.

A PKK group was chosen as the target community for this program because its members generally work as housewives and do not have regular income. Basically, the PKK of Batangkaluku already a community-based activity plan. PKK programs are oriented towards creating a healthy and comfortable environment such as activities to maintain or protect the environment. However, there are many programs that did not run optimally while, in fact, this group was deliberately formed to carry out activities in their community.

There were about 30 unproductive housewives who joined the PKK. However, only a few of them 
participated in community activities. Based on the results of an interview with one member of the PKK activator team, it was stated that the reason for the lack of active participation of the other members was due to a lack of interest in the program implemented by the community group. They preferred to do their duties as housewives rather than to carry out their functions as PKK activators in their village.

The PKK group in this village had an enormous potential in running this program. They could partake in the processing of organic waste including leftovers from sellers at the Sungguminasa Central Market. The presence of organic waste as the leftovers of fruits and vegetables sale from the sellers had created an unpleasant odor and an unfavorable sight around the market. In addition, this activity would also support the local government's programs in creating a clean and beautiful environment at the village level. Therefore, we organized the community service program in the form of processing the organic waste obtained from Sungguminasa Central Market. The waste was used as a growth medium for BSF. The program was entitled Empowering a Family Welfare Empowerment Movement Group Through Lady Kaka.

The objectives of this community service are: 1) to improve the knowledge of PKK women about how to cultivate BSF and process it into fish feed, 2) to improve the welfare of PKK women by marketing BSF cultivated products, and 3) to reduce organic waste by using it as BSF feed.

\section{METHOD}

This community service program was implemented for five months. The activity was carried out in three stages, namely the preparation stage, the implementation stage, and the monitoring and evaluation stage. Each stage was performed through a detailed procedure and was evaluated by the implementation team.

a. Preparation Stage

1) Observation

The observation was carried out by conducting a survey at the location that became the place to implement the community service program. This area was Batangkaluku Village in Gowa. The survey was carried out in two places to determine the right location to cultivate the black soldier fly.

2) Coordination

Coordination was carried out through communication with the leader of the PKK, who was also the partnership leader. Based on information obtained from the partnership leader, there were 30 PKK members; therefore, the number of partners needed to attend the training was seven people. In addition, the decision with regard to the number of partners was also adjusted to the training rules for the community service activities. One of the efforts to obtain the information about BSF cultivation was organizing a sharing session (hearing) at the Peduli Negeri Foundation, which was engaged in the farming and development of BSF.

3) Provision of Tools and Materials

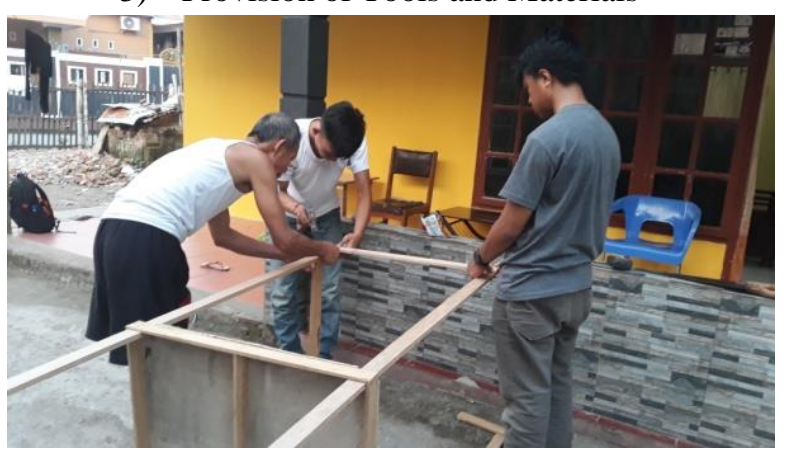

Figure 1. The making of black soldier fly cage

The provision of tools and materials was done by creating a black soldier fly cage and a place for them to lay their eggs using smoothed wood, iron nets, nails, hammers, covers, rubber bands, basins, and water shown in Figure 1. In addition, equipment and other things used for training were also prepared, such as training sites, mats and a collection of pictures related to how to cultivate the army flies and how to process the larvae (maggots) into fish feed.

b. Program Implementation

\section{1) Training}

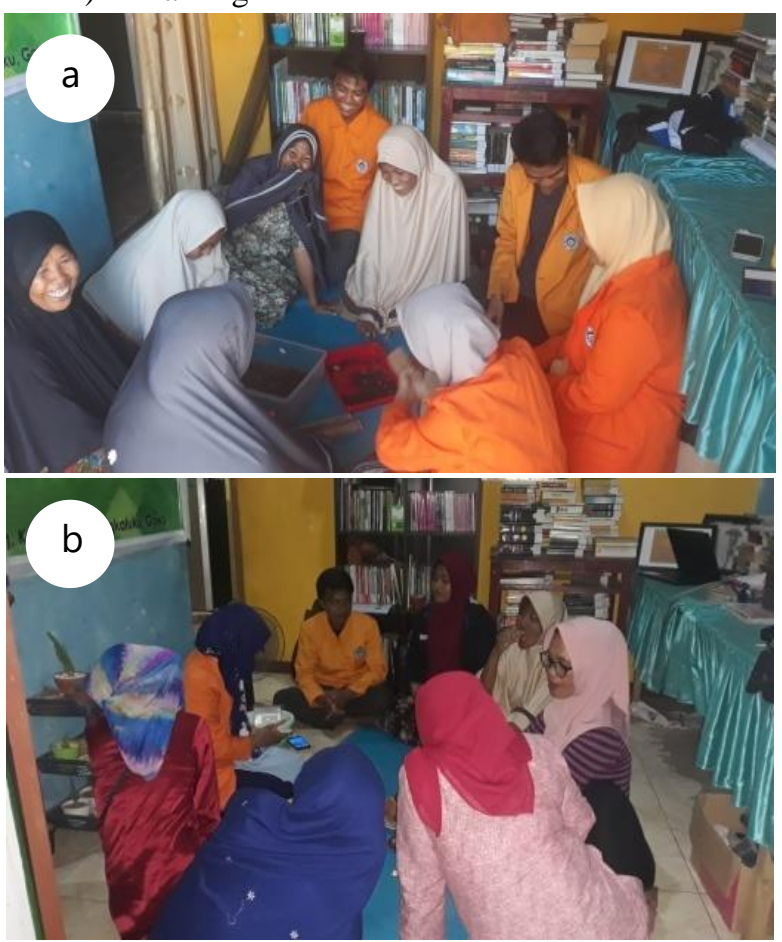

Figure 2. Training during program implementation: (a) Cultivation of black soldier flies; (b) Making of fermentation fluids and processing black soldier flies into fish feed

The training was held twice at the house of one of the partners with training material I on how to cultivate black soldier flies (Figure 2.A) and training material II on how to make fermentation liquid and process black 
soldier flies into fish feed (Figure 2.B). There was a long-time interval between the first and second training because the processing of black soldier flies into fish feed was carried out after the fly had passed one life cycle, which was approximately one and a half months.

2) Reactivation of the PKK Women

The reactivation of the PKK women was conducted by providing training to the group that had been formed as the program's partner. The training was done for PKK women to reactivate the group through community activities that can support the economy if this program can be carried out in a sustainable manner.

c. Monitoring and Evaluation

The monitoring stage was carried out to monitor and see the progress of the partner group's performance that had been formed previously. The activities carried out were maintaining fly larvae (maggots) by feeding them with organic waste twice their body weight every day and transferred them to a cage after they became pupae, harvesting fly eggs, and processing pupae and dead flies.

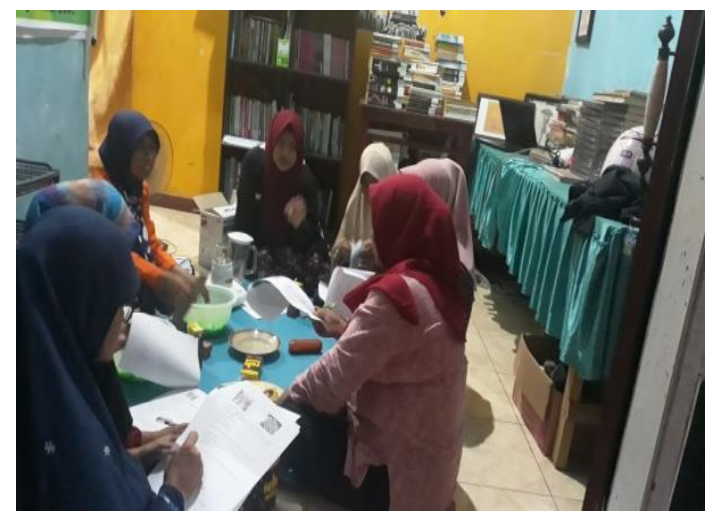

Figure 3. Pre-test and post-test implementation

The evaluation phase was carried out after the implementation activities were completed. This evaluation was done among the members of the implementation team regarding their performances, achievements, and shortcomings of each implemented stage. An evaluation was also done by the implementation team on partners to optimize activities that would be carried out (Figure 3).

\section{RESULT AND DISCUSSION}

The PKK group's knowledge of how to cultivate BSF and process them into fish feed increased as shown by the mean of the pre-test and post-test scores in Table 1. The pre-test mean score was 32.8 while the post-test mean score was 97.1. The highest score obtained on the pre-test results was 70, which was only obtained by one participant, while the lowest score was 20 , which was obtained by four participants. In the post-test results, as many as five people earned the highest score of 100 while the other two women earned the score of 90 . Based on these data, it can be seen that there was an increase in the knowledge of the women in the PKK group about how to cultivate BSF and to process them into fish feed. Table 1. Pre-Test and Post-Test Results

\begin{tabular}{ccc}
\hline Participants & Pre-Test Score & Post-Test Score \\
\hline 1 & 20 & 90 \\
2 & 70 & 100 \\
3 & 50 & 100 \\
4 & 20 & 100 \\
5 & 30 & 90 \\
6 & 20 & 100 \\
7 & 20 & 100 \\
\hline Mean & $\mathbf{3 2 . 8}$ & $\mathbf{9 7 . 1}$ \\
\hline
\end{tabular}

In addition to the pre-test and post-test results, the achievement of the community service's goals can also be seen from the production of fish feed products. Processing the pupae and dead flies into fish feed products had been carried out within 1.5 months of maintenance or one-time BSF's life cycle. Seven kilograms of maggots was only able to produce five kilograms of fish feed. According to Wardhana (2016), insects such as BSF are widely used as an alternative protein source, which is ideal to use as feed, especially young BSF larvae that can be used as fish feed because they are smaller in size and suit the size of the fish's mouth. BSF's life cycle can be seen in Figure 4.
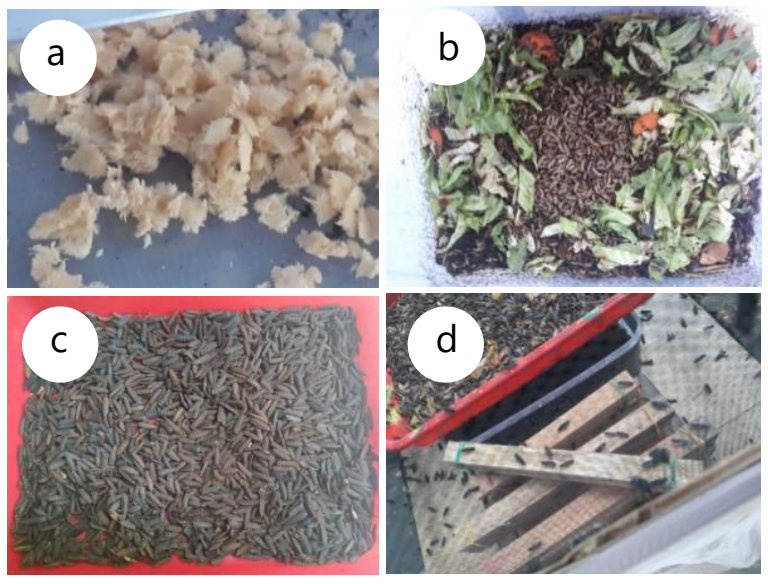

Figure 4. Black soldier fly life cycle (a) Egg phase; (b) Maggot phase; (c) Larva phase; and (d) Fly phase.

Along with the continuity of the life cycle of flies that are able to produce one cluster of eggs (500 eggs) per female, the amount of fish feed production will increase in the future. According to Donahue (2017) a female fly can produce eggs ranging from 400 to 800 pieces, and these will hatch over a period of four days. Therefore, the eggs should be placed close to organic materials to ease the larvae to find food.

The first cycle produced five kilograms of fish feed and the second cycle produced $30 \mathrm{~kg}$ of fish feed. Each pack of fish feed containing 250 grams was sold for IDR15,000 per package. Products were marketed both directly and online. The online marketing was carried out through online marketplace 
applications. The fish feed products can be seen in Figure 5.

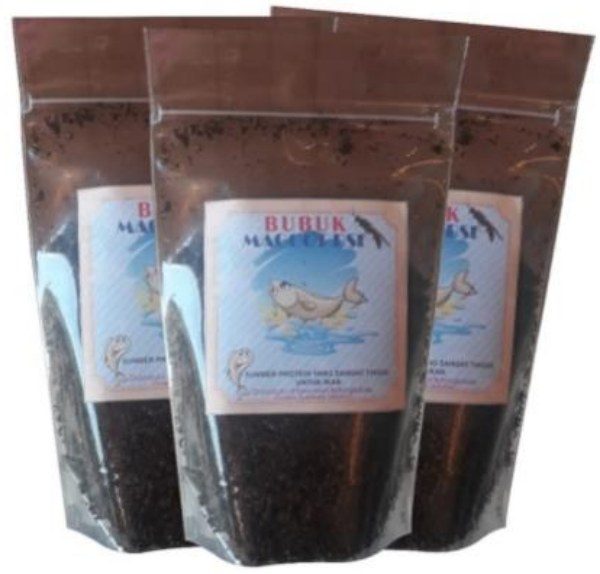

Figure 5. Fish feed products

Direct marketing was done by visiting catfish farmers in Bontomarannu District. This strategy was chosen because this product was still in the introductory stage. Even though in its introductory stage, this product was able to compete in the market due to its many advantages. The protein content in BSF is much higher than fish feed widely sold in the market, which is around $40 \%$ (Laurens, 2015); therefore, this feed is able to accelerate the fish growth which is directly proportional to the high demand for catfish in the market. In addition, the price of fish feed products from BSF cultivation was also able to compete in the market. Therefore, the welfare of PKK women had increased due to the permanent job they have had, namely cultivating BSF and processing them into fish feed. They could also earn another income from selling the fish feed products.

The reduction of organic waste in Sungguminasa Central Market could be seen from the activities of the PKK women, who collect the garbage every day. Apart from being the medium for growing BSF maggots, this waste was also the source of the maggots' food. BSF maggots' need to eat is able to use up organic waste as much as two times of its body weight; therefore, PKK women had to collect the organic waste at Sungguminasa Central Market every day.

\section{CONCLUSION}

The conclusion of this community service program is that the PKK group had become knowledgeable and skillful in cultivating BSF and processing them into fish feed. As a result, the welfare of the women in the PKK group have increased through marketing the fish fed products, and the organic waste at the central market could be reduce through the processing of BSF into fish feed.

\section{REFERENCE}

CNN Indonesia.(2018). Riset: 24 Persen Sampah di Indonesia masih Tak Terkelola. 28 April 2018 at 11.26. Accessed on 20 November 2018

Donahue, P. (2017). Proses Pengolahan Sampah Organik dengan Black Soldier Fly. Jakarta: Depertemen Pengembangan Sanitasi, Air dan Limbah Padat.

Fauzi, R. U. A., \& Eka, R. N. S. (2018). Business Analysis of Maggot Cultivation as a Catfish Feed Alternative. Jurnal Teknologi dan Manajemen Agroindustri, 7(1), 39-46. DOI: https://doi.org/10.21776/ub.industria.2018.007. $\underline{01.5}$

Laurens, A. (2015). Adopsi Protein Serangga dari Limbah Organik Sebagai Pakan Hewan di Sidoarjo, Studi Kasus Forward. Jurnal Calyptra, $4(1), 1-16$.

Korantempo.com. (2016).Pedagang Pasar Sentral Sungguminasa Akan Dikurangi.17 January 2016.Accessed on 25 December 2018.

Muhayyat, M. S., Ahmad, T.,\& Agus, P. (2016).Pengaruh Jenis Limbah dan Rasio Umpan pada Biokonversi Limbah Domestik Menggunakan Larva Black Soldier Fly. Jurnal Rekayasa Proses, 10(1), 23-29. DOI: DOI: https://doi.org/10.22146/jrekpros.34424

Pikiran Rakyat. (2017). Total Sampah di Indonesia Capai 187,2 juta ton/tahun. 1 April 2017 at 8.02.Accessed on 20 November 2018.

Sandiasa, G., \& Ida, A. P. S. W. (2017).Kebijakan Penguatan Lembaga Pemberdayaan dalam Meningkatkan Partisipasi Masyarakat di Perdesaan.Locus Majalah Ilmiah Fisip, 8(1), 6478.

Suciati, R.,\& Hilman, F. (2017). Efektifitas Media Pertumbuhan Maggots Hermietia illucens (Lalat tentara hitam) sebagai Solusi Pemanfaatan Sampah Organik. Biosfer, Jurnal Biologi dan Pendidikan Biologi, 2(1), 8-13. DOI: http://dx.doi.org/10.23969/biosfer.v2i1.35 $\underline{6}$

TribunGowa.com. (2018).Pemkab Gowa Target Bebas Sampah 2022.5 September 2018 at 9.51.Accessed on 16 December 2018.

Wardhana, A. H. (2016). Black Soldier Fly (Hermetia illucens) sebagai Sumber Protein Alternatif untuk Pakan Ternak. WARTAZOA, 26(1), 69-78. DOI:

http://dx.doi.org/10.14334/wartazoa.v26i2.1218

Wisnawa, I. G. Y.,\& I Nyoman, D. P. (2017).Pengolahan Sampah Melalui Pemanfaatan Bio Konversi Larva Lalat Tentara.Seminar Nasional Pengabdian Kepada Masyarakat (SENADIMAS): ISBN 978-6026428-12-7, 239. 
